\title{
Digestion and synthesis in the rumen of sheep given diets supplemented with free and protected oils
}

\author{
By J. D. SUTTON, R. KNIGHT,* A. B. McAllan and R. H. SMITH \\ National Institute for Research in Dairying, Shinfield, Reading RG2 $9 A T$
}

\section{(Received 24 June 1982 - Accepted 3 December 1982)}

1. Six wether sheep were each provided with a permanent cannula in the rumen and re-entrant cannulas in the proximal duodenum.

2. In a preliminary study, the sheep consumed $200 \mathrm{~g}$ hay and $400 \mathrm{~g}$ concentrates supplemented with up to $40 \mathrm{~g}$ linseed oil, coconut oil or cod-liver oil daily. Feed was refused at higher levels of supplementation.

3. Five of the sheep were used in a $5 \times 5$ Latin-square experiment. They were given $200 \mathrm{~g}$ hay and $400 \mathrm{~g}$ concentrates alone (B) or supplemented with $40 \mathrm{~g}$ linseed oil (L), coconut oil (C), protected linseed oil or protected coconut oil daily. The protected oils were prepared by emulsifying the free oils with formaldehyde-treated sodium caseinate. Formaldehyde-treated sodium caseinate was also included in the other three diets.

4. Digestion in the stomach was measured by spot sampling duodenal digesta, using chromic oxide-impregnated paper as the marker. Microbial flow at the duodenum was measured by use of both diaminopimelic acid (DAPA) and RNA as microbial markers.

5. Both the free oils had broadly similar effects despite their very different fatty acid compositions. Digestion in the stomach of organic matter (OM) was reduced from 0.48 (diet B) to 0.29 (diets $L$ and C) and that of neutral-detergent fibre from $0.50($ diet B) to $0.19(\operatorname{diet} L)$ and $0.12(\operatorname{diet} C)$. The molar proportions of acetic acid and $n$-butyric acid were decreased and that of propionic acid was increased. Protozoal numbers were reduced by $78 \%$ (diet $\mathrm{L}$ ) and $90 \%$ (diet $\mathrm{C}$ ). The flow of total nitrogen and microbial $\mathrm{N}$ was increased by both oils and the efficiency of microbial protein synthesis $(\mathrm{g} \mathrm{N} / \mathrm{kg} \mathrm{OM}$ apparently digested in the rumen) was increased from 30 (diet B) to 85 (diet L) and 74 (diet C) when based on DAPA and from 41 (diet B) to 94 (diet L) and 81 (diet C) when based on RNA. The efficiency when based on true digestion of OM $(\mathrm{g} \mathrm{N} / \mathrm{kg} \mathrm{OM}$ truly digested in the rumen) was increased from 23 (diet B) to 46 (diet L) and 44 (diet C) when based on DAPA and from 29 (diet B) to 49 (diet L) and 46 (diet C) when based on RNA. The amounts of microbial OM (g/d) at the duodenum were increased from 68 (diet B) to 124 (diet L) and 106 (diet C) when based on DAPA and from 92 (diet B) to 136 (diet L) and 115 (diet C, non-significant) when based on RNA.

6. When the oils were given in the protected form, the effects on digestion in the stomach were reduced but not eliminated. No significant increases in the amount of total $\mathrm{N}$ or microbial $\mathrm{N}$ at the duodenum were established, though there was a tendency for an increase in the efficiency of microbial protein synthesis with protected linseed oil. The results suggested that the method of protection used reduced the effects of the oils on rumen digestion and synthesis but was only partially successful in preventing hydrogenation of the fatty acids.

7. It is concluded that free oils can markedly increase the efficiency of microbial protein synthesis, possibly by their defaunating effect, and that this may enhance the potential for using non-protein- $\mathrm{N}$ on oil-supplemented diets.

Dietary lipid supplements are known to cause extensive modification to digestion in the rumen. Reductions have been demonstrated in fibre and organic matter (OM) digestion, methanogenesis, ammonia concentrations and the acetate : propionate value (Devendra $\&$ Lewis, 1974a; Palmquist \& Jenkins, 1980). More recently it has been suggested that free oils may also alter synthesis of protein and lipids by rumen microbes (Czerkawski et al. 1975; Sutton et al. 1975). The effects appear to be due partly to inhibitory activity by certain of the medium- and long-chain free fatty acids released by hydrolysis in the rumen, and partly to a physical coating of the microbes and feed particles. Methods developed for protecting lipids from rumen metabolism offer the possibility that lipids fed in such a form may interfere less with rumen metabolism, but indirect evidence from experiments with milking cows has suggested that the technique is only partly effective in this respect (Bines

* Present address: Ministry of Agriculture, Fisheries \& Food, Agricultural Development and Advisory Service, Shardlow Hall, Shardlow, Derby DE7 2GN. 
et al. 1978). No direct comparison of the effects of oils in the free and protected forms on rumen digestion appears to have been published.

The purpose of the present studies was to examine in greater detail the effects of free lipid supplements on the processes of digestion and synthesis in the rumen of sheep and to see whether the extent of these effects was reduced when the lipids were given in the protected form. A brief report of some of these results has been published previously (Knight et al. 1978).

\section{EXPERIMENTAL}

Animals and management. Six Suffolk $\times$ Scottish half-bred wether sheep, aged approximately 18 months at the beginning of the experiments and weighing approximately $40 \mathrm{~kg}$, were used. They were each fitted with a permanent cannula in the rumen and a re-entrant cannula (Ash, 1962) in the duodenum, approximately $50 \mathrm{~mm}$ beyond the pylorus and proximal to the point of entry of the common bile duct.

All the sheep were kept in individual metabolism crates indoors throughout.

Feeds. The basal feeds were chopped hay $(872 \mathrm{~g}$ dry matter (DM) $/ \mathrm{kg}$ air-dry feed; $928 \mathrm{~g}$ organic matter (OM), $19.2 \mathrm{~g}$ nitrogen and $694 \mathrm{~g}$ neutral-detergent fibre (NDF)/kg DM and a concentrate mix $(866 \mathrm{~g} \mathrm{DM} / \mathrm{kg}$ air-dry feed; $960 \mathrm{~g} \mathrm{OM}, 21.5 \mathrm{~g} \mathrm{~N}$ and $240 \mathrm{~g} \mathrm{NDF} / \mathrm{kg}$ DM consisting of $936 \mathrm{~kg}$ rolled barley, $49 \mathrm{~kg}$ groundnut meal and $15 \mathrm{~kg}$ low-copper mineral supplement (Boots Farmsales Ltd, Witney, Oxon) per tonne. To reduce the possibility of $\mathrm{Cu}$ toxicity, each sheep was provided with $1 \cdot 1 \mathrm{~g}$ anhydrous sodium sulphate and $0.02 \mathrm{~g}$ ammonium molybdate in the mix daily (Cammell, 1977).

Coconut oil, raw linseed oil and cod-liver oil (Super Solvitax; British Cod Liver Oils Ltd, Hull) were used. The linseed oil was stabilized by the addition of an antioxidant, butylated hydroxytoluene (2,6 ditert-butyl-p-cresol) to give a concentration of $0 \cdot 2 \mathrm{~g} / 1$. Protected forms of linseed oil and coconut oil were prepared by a method similar to that described by Scott et al. (1971) in which an emulsion of $8 \mathrm{~kg}$ oil, $4 \mathrm{~kg}$ sodium caseinate and $550 \mathrm{ml}$ formaldehyde solution (370-400 g/l) was prepared and spray-dried (Unigate Ltd, Bourton, Dorset). On analysis the protected products were found to contain $45 \mathrm{~g} \mathrm{~N}$ and $653 \mathrm{~g}$ total lipid $/ \mathrm{kg}$ DM. Protected sodium caseinate was used in some treatments. It was prepared by dissolving $2 \mathrm{~kg}$ sodium caseinate in 101 water at $70^{\circ}$ and adding $275 \mathrm{ml}$ formaldehyde solution. The resulting gel was dried at $80^{\circ}$ on a hot-air-bed drier and milled.

\section{Expt 1}

The first experiment was a preliminary study to compare the acceptability and rumen fermentation characteristics in sheep given the basal diet supplemented with each of the three free oils. The three oils were allocated at random to the six sheep such that each oil was offered to two sheep. The basal ration of $200 \mathrm{~g}$ hay and $400 \mathrm{~g}$ concentrate $\mathrm{mix} / \mathrm{d}$ was given in two equal portions at 06.00 and 16.30 hours. Uneaten food was removed and weighed at 16.00 hours. Drinking water was available at all times. The free oils were mixed daily by hand into the ration of concentrates. The amount of oil offered was increased by $10 \mathrm{~g}$ every $3 \mathrm{~d}$ until refusals of feed occurred. The sheep then continued on the basal diet supplemented with the highest level of oil that they would accept without refusals. After 5 weeks on the oil-supplemented diets rumen samples were taken for volatile fatty acid (VFA) analysis and protozoa counts on $3 \mathrm{~d}$ at 09.00 and 16.30 hours. Rumen samples continued to be taken on $3 \mathrm{~d}$ in each week for 6 weeks after withdrawal of the supplements.

\section{Expt 2}

Five of the six sheep in Expt 1 were used. They were given a basal diet alone or supplemented with $40 \mathrm{~g}$ daily of linseed oil or coconut oil, either in the free or protected 
forms in a $5 \times 5$ Latin-square design. The basal diet consisted of $(\mathrm{g} / \mathrm{d}) 200$ hay, 380 concentrate mix and 20 protected casein. For the two free-oil treatments, the ration of oil was mixed into the basal concentrates and protected casein daily. For the protected-oil treatments, the protected casein was omitted and $60 \mathrm{~g}$ protected-oil supplement were added. The sheep were fed at 06.00 and 18.00 hours. For 2 weeks before and during collections of duodenal digesta, $2.5 \mathrm{~g}$ chromic oxide paper, providing $0.88 \mathrm{~g} \mathrm{Cr}_{2} \mathrm{O}_{3}$, was added to the rumen at each feeding time.

Sampling. Each period consisted of $42 \mathrm{~d}$. For the first $10 \mathrm{~d}$, to reduce carry-over effects from the previous treatment, all the sheep were given the basal diet and, in addition, about $100 \mathrm{ml}$ rumen fluid from a donor sheep receiving the basal diet were added to the rumen contents of each sheep to provide an inoculum of a mixed microbial population. A period of $19 \mathrm{~d}$ was allowed for introduction of the oils and adaptation to the diets; during this time oils were increased by $10 \mathrm{~g} / \mathrm{d}$ every $2 \mathrm{~d}$ until an intake of $40 \mathrm{~g} / \mathrm{d}$ was achieved. A period of $13 \mathrm{~d}$ was then allowed for sampling as follows: days $1-9$ faecal collection by harness and bag, days 2-6 spot sampling duodenal digesta and days 9-13 rumen samples for preparation of a bacterial fraction. Small samples of rumen fluid were also taken at 09.00 and 16.30 hours on $3 \mathrm{~d}$ each week; a portion was mixed with an equal volume of glycerol-waterformalin (500:450:50, by vol.) for protozoa counts and the remainder was stored at $-20^{\circ}$. Faeces were bulked and stored at $-20^{\circ}$. Duodenal digesta was collected by blocking the distal duodenal cannula and collecting about $150 \mathrm{ml}$ digesta flowing from the proximal cannula. Twelve samples were taken from each sheep over $5 \mathrm{~d}$ to cover hourly intervals from 12.00 to 24.00 hours. The samples were bulked and stored at $-20^{\circ}$. Samples of rumen fluid (300-500 $\mathrm{ml}$ ) for bacterial preparations were taken over $5 \mathrm{~d}$ such that samples covered 0 , 3 and $5 \mathrm{~h}$ after feeding. Bacterial samples were separated by differential centrifugation as described by Smith \& McAllan (1974). Portions'were removed and extracted for RNA analysis and the remainder was stored at $-20^{\circ}$ for other analyses.

Chemical analyses. The DM content of feeds was determined by drying at $100^{\circ}$ for $2 \mathrm{~d}$. The DM content of digesta, bacterial preparations and faeces was determined by freeze-drying. Samples of feed, digesta and faeces were analysed for OM by ashing at $550^{\circ}$ for $4 \mathrm{~h}, \mathrm{~N}$ by the Kjeldahl technique, NDF (Van Soest \& Wine, 1967) and gross energy by adiabatic bomb calorimetry. Ammonia in duodenal fluid was measured by the Conway (1957) method, rumen VFA by gas-liquid chromatography (Sutton \& Johnson, 1969) and the $\mathrm{Cr}_{2} \mathrm{O}_{3}$ content of total duodenal digesta by the method of Stevenson \& de Langen (1960). Duodenal digesta and rumen bacteria were analysed for RNA by the method of McAllan \& Smith (1969) and for diaminopimelic acid (DAPA) by the method of Smith et al. (1978). Rumen bacteria samples were also analysed for $O M$ and total $N$. Lipids were extracted in chloroform-methanol $(2: 1 \mathrm{v} / \mathrm{v})$ and the fatty acids were analysed by gas-liquid chomatography of the methyl esters (Newport et al. 1979).

Calculations. Flow of digesta at the duodenum was calculated by reference to $\mathrm{Cr}_{2} \mathrm{O}_{3}$. The flow of microbial material at the duodenum was calculated from the concentration of RNA or DAPA in the separated bacterial fraction from rumen contents and in total duodenal digesta. As recent studies have established that a small proportion of the RNA at the duodenum may be of feed origin, the RNA content of duodenal digesta was multiplied by 0.85 (Smith et al. 1978). Although DAPA, unlike RNA, is generally considered to be a marker for bacteria only, for simplicity of presentation it will be described as a marker for microbial flow (i.e. bacteria and protozoa) except where a clear distinction between bacterial and protozoal contributions is discussed. In the present paper apparent digestion will be referred to as digestion whereas food minus duodenal flow plus microbial flow will be referred to as true digestion in the stomach. 


\section{RESULTS \\ Expt 1}

All the free-oil supplements were accepted when provided at up to $40 \mathrm{~g} / \mathrm{d}$ in the concentrate but some feed was uneaten when $50 \mathrm{~g} / \mathrm{d}$ were offered. Supplementation was therefore reduced to $40 \mathrm{~g} / \mathrm{d}$.

The mean molar proportions of VFA in the rumen 5 weeks after the oils were first introduced were characterized by relatively low proportions of acetic acid and, to a lesser extent, butyric acid and high proportions of propionic acid (Table 1). The number of

Table 1. Expt 1. Mean weekly values for the concentration of total volatile fatty acids (VFA), molar proportions of the major VFA and index of protozoa numbers in the rumen fluid of sheep receiving a basal diet supplemented with $40 \mathrm{~g} / \mathrm{d}$ of one of three free oils

(Each value is the mean for two sheep)

\begin{tabular}{|c|c|c|c|c|c|}
\hline \multirow{2}{*}{$\begin{array}{l}\text { Time } \\
\text { (weeks) }\end{array}$} & \multirow[t]{2}{*}{$\begin{array}{c}\text { Total } \\
\text { VFA } \\
(\mathrm{mmol} / \mathrm{l})\end{array}$} & $\begin{array}{l}\text { Acetic } \\
\text { acid }\end{array}$ & $\begin{array}{l}\text { Propionic } \\
\text { acid }\end{array}$ & $\begin{array}{l}\text { Butyric } \\
\text { acid }\end{array}$ & \multirow{2}{*}{$\begin{array}{l}\text { Protozoa nos. } \\
\text { (scale } 0-3)^{*}\end{array}$} \\
\hline & & \multicolumn{3}{|c|}{$(\mathrm{mol} / \mathrm{mol}$ total VFA) } & \\
\hline \multirow{2}{*}{\multicolumn{6}{|c|}{ After introduction }} \\
\hline & & & & & \\
\hline $\begin{array}{c}5 \\
\text { After withdrawal }\end{array}$ & 71 & 0.58 & $0 \cdot 30$ & 0.07 & 0.5 \\
\hline 1 & 78 & 0.59 & $0 \cdot 26$ & 0.09 & 1 \\
\hline 2 & 66 & 0.63 & $0 \cdot 18$ & $0 \cdot 14$ & 2 \\
\hline \multirow[t]{2}{*}{3} & 74 & 0.64 & $0 \cdot 19$ & $0 \cdot 12$ & $1 \cdot 5$ \\
\hline & & & Coconut oil & & \\
\hline \multicolumn{6}{|l|}{ After introduction } \\
\hline & \multicolumn{2}{|c|}{ After withdrawal } & $0 \cdot 27$ & $0 \cdot 09$ & 1 \\
\hline 1 & 64 & 0.61 & $0 \cdot 25$ & 0.09 & 0 \\
\hline 2 & 60 & 0.64 & $0 \cdot 16$ & $0 \cdot 13$ & 1 \\
\hline \multirow[t]{2}{*}{3} & 56 & 0.65 & $0 \cdot 17$ & $0 \cdot 13$ & 1 \\
\hline & & & Cod-liver oil & & \\
\hline After introduction & & & & & \\
\hline$\frac{5}{2}$ & 72 & 0.54 & $0 \cdot 32$ & $0 \cdot 10$ & 1.5 \\
\hline After withdrawal & & & & & \\
\hline 1 & 64 & 0.58 & $0 \cdot 25$ & $0 \cdot 11$ & 1.5 \\
\hline 2 & 61 & 0.63 & $0 \cdot 20$ & $0 \cdot 12$ & 2 \\
\hline 3 & 62 & 0.63 & $0 \cdot 19$ & $0 \cdot 13$ & 2 \\
\hline
\end{tabular}

* Scale corresponds approximately to $1 \times 10^{4} \mathrm{protozoa} / \mathrm{ml}$ at 0.5 to $5 \times 10^{5} \mathrm{protozoa} / \mathrm{ml}$ at 2.0 .

protozoa was low compared to 2 and 3 weeks after withdrawal of the oils. Rumen VFA proportions returned to stable values within 2 weeks of withdrawal of the oils.

There were no clear differences among the oils in terms of their acceptability or effects on rumen fermentation. Two oils differing widely in their fatty acid compositions were required for Expt 2 and coconut oil and linseed oil were chosen.

\section{Expt 2}

Diets were normally eaten rapidly and no refusals of feed occurred during the sampling periods. Occasionally, sheep were reluctant to eat all the feed when the maximum intake of oil was first achieved, particularly in the case of coconut oil. However, full feed consumption resumed after $2-3 \mathrm{~d}$. 
Table 2. Expt 2. Mean dry matter (DM) content and composition of the DM of the hay and of the basal concentrates supplemented with protected casein $(B)$, protected casein plus linseed oil $(L)$, protected linseed oil $(P L)$, protected casein plus coconut oil $(C)$ and protected coconut oil $(\mathrm{PCO})$

\begin{tabular}{|c|c|c|c|c|c|c|}
\hline Treatment $\ldots$ & Hay & B & $\mathrm{L}^{*}$ & $\mathrm{PL}^{*}$ & $\mathrm{C}^{*}$ & $\mathrm{PC}^{*}$ \\
\hline DM $(\mathrm{g} / \mathrm{kg}$ feed $)$ & 872 & 873 & 884 & 884 & 884 & 884 \\
\hline \multicolumn{7}{|c|}{ Composition of DM $(\mathrm{g} / \mathrm{kg})$} \\
\hline Gross energy (MJ) & $\begin{array}{r}928 \\
18 \cdot 517\end{array}$ & $\begin{array}{l}902 \\
18 \cdot 064\end{array}$ & $\begin{array}{r}900 \\
20 \cdot 285\end{array}$ & $\begin{array}{l}960 \\
20 \cdot 604\end{array}$ & $\begin{array}{l}960 \\
20 \cdot 100\end{array}$ & $\begin{array}{l}966 \\
20 \cdot 416\end{array}$ \\
\hline $\begin{array}{l}\text { Neutral-detergent } \\
\text { fibre }\end{array}$ & 694 & 226 & 203 & 203 & 203 & 203 \\
\hline Nitrogen & $19 \cdot 2$ & $28 \cdot 3$ & $25 \cdot 4$ & $25 \cdot 1$ & $25 \cdot 4$ & $25 \cdot 1$ \\
\hline
\end{tabular}

* Calculated from the mean composition of the basal concentrates and supplements which were analysed separately.

Table 3. Expt 2. The content ( $\mathrm{mg} / \mathrm{g}$ dry matter) of major fatty acids in the free and protected oil supplements

\begin{tabular}{|c|c|c|c|c|}
\hline Fatty acid & Linseed oil & $\begin{array}{l}\text { Protected } \\
\text { linseed oil }\end{array}$ & Coconut oil & $\begin{array}{l}\text { Protected } \\
\text { coconut oil }\end{array}$ \\
\hline $6: 0$ & - & - & $1 \cdot 1$ & 0.7 \\
\hline $8: 0$ & - & - & 75.5 & $53 \cdot 3$ \\
\hline $10: 0$ & - & - & 46.4 & 34.0 \\
\hline $12: 0$ & - & - & 445.9 & $309 \cdot 6$ \\
\hline $14: 0$ & $\ldots$ & 1.0 & $163 \cdot 4$ & $109 \cdot 3$ \\
\hline $16: 0$ & $56 \cdot 1$ & 37.8 & $74 \cdot 2$ & $50 \cdot 3$ \\
\hline $16: 1$ & 1.8 & - & - & - \\
\hline $18: 0$ & $35 \cdot 1$ & 22.6 & $22 \cdot 2$ & $14 \cdot 6$ \\
\hline $18: 1$ & $173 \cdot 2$ & 111.4 & 60.8 & $42 \cdot 5$ \\
\hline $18: 2$ & 148.9 & 94.7 & 15.0 & $9 \cdot 7$ \\
\hline $18: 3$ & 555.9 & $363 \cdot 2$ & $1 \cdot 1$ & 0.4 \\
\hline $20: 0$ & $2 \cdot 5$ & 1.8 & - & - \\
\hline Others & $10 \cdot 1$ & 6.7 & $14 \cdot 1$ & $5 \cdot 2$ \\
\hline
\end{tabular}

The mean compositions of the hay and the various supplemented concentrates are shown in Table 2 and the fatty acid contents of the free- and protected-oil supplements are shown in Table 3.

The intake and digestion of $\mathrm{OM}$ are given in Table 4. Digestion in the total tract was reduced by both free oils but was unaffected by the protected oils. The amount of OM entering the duodenum was increased by all the supplements but the increase was greater for the oils in the free form than in the protected form. This increase partly reflected the higher intake on the supplemented diets but a bigger contributor, particularly with the free oils, was a large depression in digestion in the stomach. Digestion was reduced by $40 \%$ of the free oils, but the reduction was only $21 \%$ with the protected linseed oil and it did not attain significance for protected coconut oil. Associated with the reduced digestion in the stomach was a reduction in the contribution of digestion in the stomach to over-all digestion of $37 \%$ for the free oils but rather less for the protected oils. Thus, whereas only $37 \%$ of OM digestion occurred in the intestines on the basal diet, this was increased to $60 \%$ with the free oils. 
Table 4. Expt 2. The mean amounts $(\mathrm{g} / \mathrm{d})$ of organic matter $(O M)$ consumed, passing to the duodenum and excreted in the faeces and its apparent digestion in the stomach and total tract of five sheep given a basal diet alone $(B)$ or supplemented with $40 \mathrm{~g} / \mathrm{d}$ linseed oil or coconut oil in the free $(L, C)$ or protected $(P L, P C)$ forms

(Each value is the mean for five sheep)

\begin{tabular}{|c|c|c|c|c|c|c|}
\hline Treatment $\ldots$ & B & $\mathbf{L}$ & PL & C & $\mathrm{PC}$ & SEM \\
\hline \multicolumn{7}{|l|}{$\mathrm{OM}(\mathrm{g} / \mathrm{d})$} \\
\hline Food & 490 & 532 & 537 & 529 & 531 & $2 \cdot 3$ \\
\hline Duodenum & 255 & $378^{* * *}$ & $333^{* * *}$ & $377^{* * *}$ & $299^{* *}$ & $8 \cdot 4$ \\
\hline Faeces & 116 & $142^{* * *}$ & 128 & $152^{* * * *}$ & 126 & $4 \cdot 2$ \\
\hline \multicolumn{7}{|l|}{ Digestion } \\
\hline Stomach & 0.48 & $0 \cdot 29 * * *$ & $0 \cdot 38^{* * *}$ & $0 \cdot 29 * * *$ & 0.44 & 0.016 \\
\hline Total tract & 0.76 & $0.73^{*}$ & 0.76 & $0.71^{* * *}$ & 0.76 & 0.008 \\
\hline$\frac{\text { Stomach }}{\text { Total tract }}$ & 0.63 & $0 \cdot 40^{* * *}$ & $0 \cdot 50^{* *}$ & $0 \cdot 40^{* * *}$ & 0.57 & 0.021 \\
\hline
\end{tabular}

Differences between the supplemented diets and the basal diet were significant: ${ }^{*} P<0.05,{ }^{* *} P<0.01$, ***P $<0.001$.

Table 5. Expt 2. The mean amounts $(M J / d)$ of gross energy passing to the duodenum and excreted in the faeces and its apparent digestion in the stomach and total tract of five sheep given a basal diet alone $(B)$ or supplemented with $40 \mathrm{~g} / \mathrm{d}$ linseed oil or coconut oil in the free $(L, C)$ or protected $(P L, P C)$ forms

(Each value is the mean for five sheep)

\begin{tabular}{|c|c|c|c|c|c|c|}
\hline Treatment $\ldots$ & B & $\mathbf{L}$ & PL & $\mathrm{C}$ & PC & SEM \\
\hline \multicolumn{7}{|c|}{ Gross energy $(\mathrm{MJ} / \mathrm{d})$} \\
\hline Food & $9 \cdot 457$ & $10 \cdot 979$ & $11 \cdot 250$ & 10.967 & $11 \cdot 105$ & 0.0422 \\
\hline Duodenum & $5 \cdot 288$ & $8.466 * * *$ & $7 \cdot 477^{* *}$ & $8 \cdot 008^{* * *}$ & $6.501^{* * *}$ & $0 \cdot 1884$ \\
\hline Faeces & 2.431 & $3 \cdot 083^{* * *}$ & $2 \cdot 806^{*}$ & $3 \cdot 212^{* * *}$ & $2 \cdot 701$ & 0.0951 \\
\hline \multicolumn{7}{|l|}{ Digestion } \\
\hline Stomach & 0.44 & $0 \cdot 23 * * *$ & $0 \cdot 34^{* *}$ & $0 \cdot 27 * * *$ & 0.41 & $0 \cdot 019$ \\
\hline Total tract & 0.74 & 0.72 & 0.75 & $0 \cdot 71^{*}$ & 0.76 & 0.009 \\
\hline$\frac{\text { Stomach }}{\text { Total tract }}$ & 0.59 & $0.32 * * *$ & $0.45^{* *}$ & $0 \cdot 38 * * *$ & 0.55 & 0.025 \\
\hline
\end{tabular}

Differences between the supplemented diets and the basal diet were significant: ${ }^{*} P<0 \cdot 05,{ }^{*} P<0 \cdot 01$, *** $P<0.001$.

The intake and digestion of energy are shown in Table 5. The results were closely similar to those for OM.

All the supplements caused large depressions in the digestion of NDF in the stomach (Table 6). The depression was particularly large with the free oils, amounting to $62 \%$ for linseed oil and $76 \%$ for coconut oil, but even in the protected form, linseed oil and coconut oils reduced digestion by $42 \%$ and $24 \%$ respectively. The oils also caused large reductions in digestion throughout the digestive tract, the effect of the free oils again being greater than the effect of the protected oils, but the depression was smaller for digestion in the total tract than for digestion in the stomach. In consequence, although only $24 \%$ of NDF digestion occurred post-ruminally on the basal diet, the percentage increased to $35-49 \%$ with the protected oils and $63-74 \%$ with the free oils. Thus increased post-ruminal digestion compensated to a considerable extent for the severe depression in rumen digestion caused by the oils. 
Table 6. Expt 2. The mean amounts $(\mathrm{g} / \mathrm{d})$ of neutral-detergent fibre (NDF) passing to the duodenum and excreted in the faeces and its apparent digestion in the stomach and total tract of five sheep given a basal diet alone (B) or supplemented with $40 \mathrm{~g} / d$ linseed oil or coconut oil in the free $(L, C)$ or protected $(P L, P C)$ forms

(Each value is the mean for five sheep)

\begin{tabular}{|c|c|c|c|c|c|c|}
\hline Treatment $\ldots$ & B & L & PL & $\mathrm{C}$ & PC & SEM \\
\hline \multicolumn{7}{|l|}{ NDF $(g / d)$} \\
\hline Food & 199 & 200 & 199 & 198 & 199 & 0.5 \\
\hline Duodenum & 99 & $160^{* * *}$ & $141^{* *}$ & $173^{* * *}$ & $124^{*}$ & $7 \cdot 6$ \\
\hline Faeces & 68 & $94 * * *$ & $83^{* * *}$ & $106^{* * * *}$ & $84^{* *}$ & $2 \cdot 9$ \\
\hline \multicolumn{7}{|l|}{ Digestion } \\
\hline Stomach & 0.50 & $0.19 * * *$ & $0 \cdot 29 * *$ & $0 \cdot 12^{* * *}$ & $0.38^{*}$ & 0.041 \\
\hline Total tract & 0.66 & $0.53^{* * *}$ & $0 \cdot 59^{* *}$ & $0.46^{* * *}$ & $0 \cdot 58^{* *}$ & 0.014 \\
\hline$\frac{\text { Stomach }}{\text { Total tract }}$ & 0.76 & $0 \cdot 37^{* *}$ & $0 \cdot 51^{*}$ & $0 \cdot 26^{* * *}$ & 0.65 & 0.078 \\
\hline
\end{tabular}

Differences between the supplemented diets and the basal diet were significant; ${ }^{*} P<0.05,{ }^{* * P}<0.01$, $* * * P<0.001$.

Table 7. Expt 2. The mean concentration of total volatile fatty acids $(V F A)(m m o l / l)$, molar proportions of the individual $V F A$ and the protozoa numbers $\left(\times 10^{-4} / \mathrm{ml}\right)$ in the rumen fluid of five sheep given a basal diet alone $(B)$ or supplemented with $40 \mathrm{~g} / \mathrm{d}$ linseed oil or coconut oil in the free $(L, C)$ or protected $(P L, P C)$ forms

(Each value is the mean for five sheep)

\begin{tabular}{|c|c|c|c|c|c|c|}
\hline Treatment $\ldots$ & B & $\mathrm{L}$ & PL & $\mathrm{C}$ & PC & SEM \\
\hline Total VFA (mmol/1) & $59 \cdot 3$ & $58 \cdot 2$ & $57 \cdot 8$ & $63 \cdot 4$ & $62 \cdot 4$ & $2 \cdot 24$ \\
\hline \multicolumn{7}{|l|}{$\begin{array}{l}\text { Molar proportions } \\
\text { (mol/mol total VFA): }\end{array}$} \\
\hline Acetic acid & 0.651 & $0.542^{* * *}$ & $0.615^{* *}$ & $0.521 * * *$ & 0.642 & 0.0077 \\
\hline Propionic acid & 0.179 & $0.333^{* * *}$ & $0.237^{* *}$ & $0 \cdot 374^{* * *}$ & $0 \cdot 211$ & 0.0093 \\
\hline Isobutyric acid & 0.011 & 0.010 & $0.014^{* *}$ & $0.005^{* * *}$ & 0.010 & 0.0006 \\
\hline$n$-Butyric acid & $0 \cdot 127$ & $0 \cdot 082^{* * *}$ & $0.093^{* *}$ & $0.076^{* * *}$ & $0 \cdot 105^{* *}$ & 0.0057 \\
\hline Isovaleric acid & 0.017 & 0.019 & $0.024^{* *}$ & $0.006 * * *$ & 0.016 & 0.0013 \\
\hline$n$-Valeric acid & 0.013 & 0.013 & 0.016 & $0.018^{*}$ & 0.015 & 0.0014 \\
\hline n-Caproic acid & 0.002 & $0 \cdot 000^{* *}$ & 0.002 & $0 \cdot 001$ & 0.003 & 0.0004 \\
\hline Protozoa numbers $\left(10^{-4} / \mathrm{ml}\right)$ & $85 \cdot 1$ & $18 \cdot 8^{* * *}$ & $45 \cdot 9 * *$ & $8 \cdot 5^{* * *}$ & $63 \cdot 4$ & $7 \cdot 26$ \\
\hline
\end{tabular}

Differences between the supplemented diets and the basal diet were significant: ${ }^{*} P<0 \cdot 05,{ }^{* *} P<0 \cdot 01$, $* * * P<0.001$.

Oil supplementation of the diet had no effect on the concentration of total VFA but marked changes in the molar proportions of individual VFA were observed (Table 7). Both free oils caused large reductions in the molar proportions of acetic acid and $n$-butyric acid and approximately doubled the proportion of propionic acid. In addition, coconut oil caused large reductions in the proportions of isobutyric acid and isovaleric acid, whereas linseed oil was without effect. The effects of linseed oil in the protected form were similar to those of the free oil but considerably less marked except in the case of isobutyric and isovaleric acids, both of which were increased. Protected coconut oil had only very small and generally non-significant effects on rumen VFA.

The numbers of protozoa were greatly reduced by the free oils but, as with changes in VFA, the effects were less marked with the protected oils. Protected linseed oil almost halved the numbers of protozoa but protected coconut oil was without significant effect. 
In addition to the rumen samples taken during the sampling period, samples were also taken throughout the experiment. The results indicated that, following withdrawal of the oils, proportions of rumen VFA and protozoa numbers returned to values found on the basal diet by the end of the $10 \mathrm{~d}$ recovery period at the beginning of each experiment period and, further, that the main effects of the oils on rumen fermentation were achieved within $5 \mathrm{~d}$ of the full treatments being applied.

Table 8. Expt 2. The mean amounts $(\mathrm{g} / \mathrm{d})$ of total nitrogen consumed, passing to the duodenum and excreted in the faeces and the flow $(\mathrm{gN} / \mathrm{d})$ of some nitrogenous constituents in duodenal digesta in five sheep given a basal diet alone $(B)$ or supplemented with $40 \mathrm{~g} /$ d linseed oil or coconut oil in the free $(L, C)$ or protected $(P L, P C)$ forms

(Each value is the mean for five sheep)

\begin{tabular}{|c|c|c|c|c|c|c|}
\hline Treatments & B & L & PL & $\mathrm{C}$ & $\mathrm{PC}$ & SEM \\
\hline \multicolumn{7}{|l|}{ Total N } \\
\hline Food & $12 \cdot 87$ & $12 \cdot 70$ & 12.97 & 12.78 & $12 \cdot 91$ & 0.087 \\
\hline Duodenum & $15 \cdot 41$ & $18 \cdot 81^{*}$ & $16 \cdot 50$ & $19 \cdot 90^{* *}$ & $14 \cdot 68$ & 0.865 \\
\hline Faeces & 3.61 & $3 \cdot 66$ & 3.23 & $3 \cdot 60$ & $3 \cdot 14^{*}$ & 0.128 \\
\hline \multicolumn{7}{|l|}{$\begin{array}{l}\mathrm{N} \text { flow in the } \\
\text { duodenal digesta }\end{array}$} \\
\hline Ammonia-N & $1 \cdot 17$ & $1 \cdot 14$ & $1 \cdot 32$ & $1 \cdot 15$ & $1 \cdot 19$ & 0.085 \\
\hline Non-ammonia-N & $14 \cdot 24$ & $17.67^{*}$ & $15 \cdot 18$ & $18 \cdot 75^{* * *}$ & $13 \cdot 21$ & 0.827 \\
\hline \multicolumn{7}{|l|}{ Microbial $N \dagger$} \\
\hline (a) DAPA & 7.07 & $12 \cdot 75^{* * *}$ & $9 \cdot 20$ & $10 \cdot 18^{* *}$ & 8.42 & 0.718 \\
\hline (b) RNA & 9.54 & $13.90^{*}$ & 13.00 & 12.44 & $10 \cdot 28$ & $1 \cdot 230$ \\
\hline
\end{tabular}

Differences between the supplemented diets and the basal diet were significant: ${ }^{*} P<0 \cdot 05,{ }^{* *} P<0 \cdot 01$, $* * * P<0.001$.

$\uparrow$ Based on the use of (a) diaminopimelic acid (DAPA) or (b) RNA as the microbial marker.

The amounts of total $\mathrm{N}$ in the food, duodenal digesta and faeces and various components of total $\mathrm{N}$ in duodenal digesta are show in Table 8. With all the diets, the amount of $\mathrm{N}$ passing to the duodenum exceeded the amount consumed. On the basal diet the increase ws $2.5 \mathrm{~g} / \mathrm{d}$ and broadly similar increases were obtained with the protected oils, but with free-oil supplementation it increased to $6 \cdot 1$ (linseed oil) and $7 \cdot 1$ (coconut oil) $\mathrm{g} / \mathrm{d}$. The amount of total $\mathrm{N}$ entering the duodenum from the stomach was approximately $20 \%$ and $30 \%$ greater with linseed oil and coconut oil respectively than with the basal diet, whereas with the protected oils the flow of total $\mathrm{N}$ was similar to that on the basal diet. No differences were detected among the treatments in the amount of ammonia- $\mathrm{N}$ so effects of the treatments on the amounts of non-ammonia- $\mathrm{N}$ closely reflected the effects on total $\mathrm{N}$. Estimates of microbial $\mathrm{N}$ based on DAPA as the marker indicated that the increase in total $\mathrm{N}$ was primarily due to large increases in microbial protein synthesis. When RNA was the marker, all estimates of microbial $\mathrm{N}$ flow were higher and, although the free oils were again found to cause increases in the amount of microbial $\mathrm{N}$, the increases were smaller and were only significnt in the case of free linseed oil. The protected oils generally had only small and non-significant effects on $\mathrm{N}$ components of duodenal digesta though there was a tendency for microbial $\mathbf{N}$ to increase, particularly with protected linseed oil. Faecal $\mathbf{N}$ was unaffected by the free oils but it was reduced by both the protected oils, significantly $(P<0.05)$ so in the case of protected coconut oil. This suggests that the extent of protection of the casein may have been less in the commerically-prepared products than in the protected casein prepared in the laboratory. However, in vitro incubation of the three protected products in rumen contents before the start of the experiment had shown ammonia production from all three products to be almost completely inhibited. 
Table 9. Expt 2. The mean amount of microbial organic matter $(O M)$ at the duodenum, the mean amount of $O M$ digested in the stomach and the efficiency of microbial protein synthesis in the stomach of five sheep given a basal diet alone $(B)$ or supplemented with $40 \mathrm{~g} / \mathrm{d}$ linseed oil or coconut oil in the free $(L, C)$ or protected $(P L, P C)$ forms

(Each value is the mean for five sheep)

\begin{tabular}{|c|c|c|c|c|c|c|}
\hline Treatment $\ldots$ & B & L & PL & $\mathrm{C}$ & PC & SEM \\
\hline \multicolumn{7}{|l|}{ Microbial OM $(\mathrm{g} / \mathrm{d}) \dagger$} \\
\hline (a) DAPA & 68 & $124^{* * *}$ & 89 & $106^{* *}$ & 75 & $8 \cdot 1$ \\
\hline (b) RNA & 92 & $136^{*}$ & 127 & 115 & 92 & $12 \cdot 7$ \\
\hline \multicolumn{7}{|l|}{$\begin{array}{l}\text { OM digested in } \\
\text { stomach }(\mathrm{g} / \mathrm{d})\end{array}$} \\
\hline Apparent $\left(\mathrm{ADOM}_{\mathbf{R}}\right)$ & 235 & $154^{* * *}$ & $204^{*}$ & $152^{* * *}$ & 232 & 8.4 \\
\hline \multicolumn{7}{|l|}{ True $\left(\right.$ TDOM $\left._{R}\right) \dagger$} \\
\hline (a) DAPA & 303 & 278 & 293 & $258^{* *}$ & 307 & $9 \cdot 1$ \\
\hline (b) RNA & 327 & $290^{*}$ & 331 & $267^{* *}$ & 324 & $11 \cdot 2$ \\
\hline \multicolumn{7}{|l|}{$\begin{array}{l}\text { Efficiency of microbial } \\
\text { protein synthesis } \dagger \\
g N / k g\end{array}$} \\
\hline $\begin{array}{l}\mathrm{g} \mathrm{N} / \mathrm{kg} \mathrm{ADOM} \\
\text { (a) DAPA }\end{array}$ & 30 & $85^{* * * *}$ & 46 & $74^{* * *}$ & 37 & 6.4 \\
\hline (b) RNA & 41 & $94^{* *}$ & 64 & $81^{* *}$ & 44 & 8.9 \\
\hline \multicolumn{7}{|l|}{$\mathrm{g} \mathrm{N} / \mathrm{kg}$ TDOM $_{\mathrm{R}}$} \\
\hline (a) DAPA & 23 & $46^{* * *}$ & 31 & $44^{* * *}$ & 27 & $5 \cdot 5$ \\
\hline (b) RNA & 29 & $49 * * *$ & $39^{*}$ & $46^{* *}$ & 31 & $6 \cdot 4$ \\
\hline
\end{tabular}

Differences between the supplemented diets and the basal diet were significant: ${ }^{*} P<0.05, \quad{ }^{* *} P<0.01$, $* * * P<0 \cdot 001$.

$\dagger$ Based on the use of (a) diaminopimelic acid (DAPA) and (b) RNA as the microbial marker.

Further details of microbial synthesis in the rumen are given in Table 9. The effect of treatments on the amount of microbial $O M$ at the duodenum was very similar to the effect on the amount of microbial $\mathrm{N}$. A consequence of the increased flow of microbial $\mathrm{OM}$ with the free oils was that, although the oils depressed the amount of OM apparently digested in the rumen by $35 \%(P<0.01)$ their effect on the amount of OM truly digested was much less, being approximately $15-20 \%$ with coconut oil $(P<0.01)$ and approximately $10 \%$, and significant $(P<0.05)$ only with RNA as the marker, with linseed oil. There were no significant effects of the protected oils on the amount of OM truly digested in the stomach.

The efficiency of microbial protein synthesis in relation to apparent or true OM digestion was always less when based on DAPA than when based on RNA. However, the free oils clearly caused large increases whichever of the four methods of calculating efficiency was used. There were no significant differences between the oils, so the mean effect in relation to apparent digestion of OM was an increase of $165 \%$ based on DAPA or $113 \%$ based on RNA. When related to truly-digested OM, the increases were 96 and $64 \%$ for the two markers respectively. Small increases were observed with the protected oils, particularly protected linseed oil, but only in one instance did the increase achieve significance $(P<0.05)$.

\section{DISCUSSION}

Free oils and digestion in the rumen

The considerable depression caused by the free oils in the digestion of $O M$ in the rumen is in agreement with the observations of Devendra \& Lewis $(1974 b)$ who gave $80 \mathrm{~g}$ maize oil or tallow $/ \mathrm{kg}$ diet to sheep receiving $1100 \mathrm{~g} / \mathrm{d}$ of two basal diets containing either 100 or $700 \mathrm{~g}$ hay $/ \mathrm{kg}$ diet. However, the depression they found averaged only $10 \%$ for the 
low-roughage diet and $15 \%$ for the high-roughage diet compared with the value of $40 \%$ found in the present studies with diets supplemented with $67 \mathrm{~g}$ oil $/ \mathrm{kg}$ diet. In contrast, Sutton et al. (1975) found no significant depression in OM digestion in the rumen of sheep when a diet of hay and concentrates was supplemented with $33 \mathrm{~g}$ cod-liver oil $/ \mathrm{kg}$. This difference may be explained by the recent experiment of Ikwuegbu \& Sutton (1982) who confirmed the large depression in OM digestion in the rumen caused by linseed oil, but who also found that the size of the depression was related to the amount of free oil included in the diet. In their experiments, Devendra \& Lewis $(1974 b)$ found that the depression caused by maize oil was greater than that caused by tallow. It seems probable that the addition to diets of free oils will frequently reduce OM digestion in the rumen but that the size of the depression will depend on the amount and nature of oil supplement and the type of basal diet.

The major cause of the depression in rumen digestion was the severe reduction in the digestion of NDF. Equally large depressions in the digestion of crude fibre due to maize oil or tallow supplementation were reported by Devendra \& Lewis $(1974 b)$ but no effect on the digestion of acid-detergent fibre due to cod-liver-oil supplementation was found by Sutton et al. (1975). The causes of the depression and more detailed analysis of individual carbohydrates are considered elsewhere (McAllan et al. 1983). Whereas $100 \mathrm{~g} \mathrm{NDF} / \mathrm{d}$ were digested in the rumen on the basal diet, this was reduced to $40 \mathrm{~g} / \mathrm{d}$ with linseed oil and only $25 \mathrm{~g} / \mathrm{d}$ with coconut oil. This reduction of 60 and $75 \mathrm{~g} \mathrm{NDF} / \mathrm{d}$ exceeds the depression of 25 and $45 \mathrm{~g} \mathrm{OM} / \mathrm{d}$ truly digested in the stomach for the two oils respectively. It is unlikely that the digestion of any major dietary constituent was increased by the oil supplements so the discrepancy probably reflects the difficulties in accurately defining the various constituents of duodenal digesta (Sutton, 1979). Despite these difficulties it is apparent that the reduction in fibre digestion is the main cause of the reduced digestion of OM and energy in the rumen.

The amount of NDF digested in the intestines was more than doubled from $31 \mathrm{~g} / \mathrm{d}$ on the basal diet to over $65 \mathrm{~g} / \mathrm{d}$ with the free oils. The ability of the hind-gut to compensate for reduced fibre digestion in the rumen was reported earlier by Thomson et al. (1972), who found that the reduced digestion of cellulose and hemicellulose in the rumen due to grinding and pelleting lucerne (Medicago sativa) was associated with increases of up to $50 \%$ in post-ruminal digestion. However, the amount of compensation in the present studies, though incomplete, was even greater than this and emphasized the considerable digestive capacity of the hind-gut fermentation of sheep.

Although the pattern of rumen VFA was markedly altered by the oil supplements, as has been found in many other studies, no change in the concentration of total VFA occurred. The amount of OM apparently digested in the rumen, which is an approximate measure of the amount of fermentation and hence VFA production in the rumen (Sutton, 1979), was reduced by $35 \%$ and an approximately equivalent reduction in VFA production would be expected. Similar results have recently been reported for diets supplemented with 20,39 or $60 \mathrm{~g}$ linseed oil $/ \mathrm{kg}$ (Ikwuegbu \& Sutton, 1982). Hence it must be concluded that the linear relationship of the concentration of VFA in the rumen to their rate of production for certain diets (Leng, 1970) does not apply when free oils are added to the diet.

\section{Free oils and microbial protein synthesis}

The very large increase in the efficiency of microbial protein synthesis when the diets were supplemented with the free oils was unexpected. Because of the accompanying depression in OM digestion, the increase in the amount of microbial protein synthesized was considerably less than the increase in efficiency of synthesis. The increase in the daily flow of total $\mathbf{N}$ in duodenal digesta due to oil supplementation was similar in size to the increase 
in microbial N, and examination of the results of Devendra \& Lewis (1974b) shows that in that experiment also, duodenal $\mathrm{N}$ was increased by $25-100 \%$ by oil supplementation. On the other hand, Sutton et al. (1975) found no effect of supplementation with cod-liver oil on the amounts of total $\mathrm{N}$ or microbial $\mathrm{N}$ at the duodenum. Czerkawski et al. (1975) concluded that supplementation of a dried-grass diet with up to $100 \mathrm{~g}$ linseed oil $/ \mathrm{kg}$ diet actually decreased the synthesis of microbial matter though it appeared to increase the rate of VFA production. These conclusions were based on concentrations and outflow rates in the rumen rather than measurements of digesta flow at the duodenum, but if they are correct, the efficiency of microbial protein synthesis was reduced in the work of Czerkawski et al. (1975) in comparison with the two- to threefold increase in our experiment.

Many methods exist for measuring the flow of digesta at the duodenum and measuring microbial protein. The methods used in the present experiment were similar to those by Ikwuegbu \& Sutton (1982). The use of $\mathrm{Cr}_{2} \mathrm{O}_{3}$ with spot sampling has been criticized (Faichney, 1975) but mainly in relation to spot sampling from simple cannulas. However, Corse \& Sutton (1971) found no differences in estimates of DM flow in the duodenum of sheep betwen total collections and spot collections of digesta from re-entrant cannulas when $\mathrm{Cr}_{2} \mathrm{O}_{3}$ was the marker. The choice of microbial marker presents even greater room for disagreement. Large but inconsistent differences have been shown by direct comparisons among different techniques (see Harrison \& McAllan, 1980). In the present studies RNA, which measures protozoa as well as bacteria, gave consistently higher estimates of flow than DAPA which measures bacteria only. This difference would appear reasonable for the basal diet and suggests that approximately $25 \%$ of microbial $\mathrm{N}$ entering the duodenum was of protozoal origin, a value similar to that reported by Harrison et al. (1979). However, on the oil-supplemented diets the difference, though smaller, was not reduced to the same extent as the reduction in protozoal numbers.

No satisfactory means exist at present for establishing the absolute accuracy of estimates of microbial protein synthesis in the complex situation of the normally-fed ruminant. The estimate for the basal ration in the present study that $30 \mathrm{~g}$ microbial $\mathrm{N}$ were synthesized $/ \mathrm{kg}$ OM apparently digested in the rumen when DAPA was the marker is identical to the mean value adopted by the Agricultural Research Council (1980). Furthermore, the proportion of OM digestion apparently occurring in the rumen on the basal diet, 0.63 , was also very close to the mean value of 0.65 adopted by the Agricultural Research Council (1980). These results show that, for the basal diet, the techniques used in the present study yielded values very similar to those published elsewhere. It is recognized that this does not provide direct evidence for the accuracy of the results obtained on the oil-supplemented diets and it would obviously be important to obtain confirmation of the results by other techniques.

The calculated efficiences of microbial protein synthesis on the two oil-supplemented diets were two to three times greater than those on the basal diet and considerably greater than even the highest previously-published values from in vivo experiments. The supplements used in the present experiment had a high energy concentration but this is unlikely to explain the high efficiency of microbial synthesis. Dietary oils are hydrolysed in the rumen and the fatty acids are extensively hydrogenated, but there is no evidence that they are catabolized. They could not, therefore, have contributed directly to the energy supply of the microbes and explanations must be sought in indirect effects of the oils.

Many factors have been shown to alter the efficiency of microbial protein synthesis (see Harrison \& McAllan, 1980). High propionate fermentations have been associated with increased ATP production and hence greater microbial yields, but this association has not been observed in all instances (Bergen \& Yokoyama, 1977) and may not apply in the present situation in which the increased proportion of propionic acid was due to the oil supplements rather than an alteration of the type of dietary carbohydrate as is the more common 
situation. A more likely explanation is the reduction in protozoal numbers due to supplementation with free oils. Such reductions due to supplementation with linseed oil or its hydrolysate have been found by others (Czerkawski et al. 1975; Van Nevel \& Demeyer, 1981; Ikwuegbu \& Sutton, 1982). Demeyer \& Van Nevel (1979) found in in vitro studies that defaunation resulted in the energetic efficiency of the net synthesis of microbial protein being approximately doubled from 13 to $30 \mathrm{~g}$ microbial $\mathrm{N} / \mathrm{kg}$ OM fermented. This expression of efficiency is similar to the term $\mathrm{g}$ microbial $\mathrm{N} / \mathrm{kg} \mathrm{OM}$ truly digested in the rumen used in the present paper and the size of the increase was similar to that caused by the oil supplements in the present study. However, in subsequent in vitro experiments, while confirming this response, Van Nevel \& Demeyer (1981) also concluded that defaunating agents such as linseed oil hydrolysate can reduce protein synthesis by bacteria by a direct toxic effect, and that the net effect on protein synthesis by the complete microbial population depends, therefore, on a balance between an increase in synthesis due to defaunation and a decrease due to the direct toxic effect of the agent on bacterial metabolism. In vivo studies by Ikwuegbu \& Sutton (1982), in which sheep were given diets containing different amounts of linseed oil, appeared to confirm this conclusion. On the other hand, efficiencies were well within the nomal range in young calves in which only very small numbers of protozoa had become established (Smith et al. 1978), suggesting that low numbers of protozoa per se, even without use of a defaunating agent, do not automatically result in high efficiencies. Clearly, more detailed studies of microbial metabolism and the role of protozoa will be required to resolve these problems satisfactorily.

\section{Protected lipids}

In almost all aspects of digestion and synthesis examined in this experiment, the effects of the protected lipids were intermediate between those of the basal diet and the two free lipids and further, the effects of protected coconut oil were generally less than those of protected linseed oil and only rarely differed significantly from the responses on the basal diet. These results show that the method of protection used greatly reduced the effects of the oils on fibre digestion, rumen VFA and microbial synthesis. The reason for the difference in response to the two protected oils is unclear. When given in the free form, the two oils had similar effects and both protected oils were prepared in exactly the same way.

Although these results indicate that the method of protection was successful in reducing the effects of dietary lipids on rumen metabolism, examination of fatty acids entering the duodenum in the digesta showed that the technique was far less effective in preventing metabolism of fatty acids in the protected lipids themselves (Knight et al. 1977).

Hogan et al. (1972) supplemented a basal diet of lucerne hay with sunflower oil protected by a similar method to that used in the present studies. They found a reduction in OM digestion in the rumen on the supplemented diet similar to that reported here. They also concluded that the formaldehyde treatment effectively protected the casein and part of the basal lucerne hay from rumen digestion but, as in the present study, it was only partially effective in protecting the fatty acids from hydrogenation. Hogan et al. (1972) suggested that these apparent discrepancies may be because the oil droplets are close to the surface of the particles and hence some hydrogenation could occur even if the casein remained protected. It is also possible that the extent of protection resulted in a release of oil or fatty acids into the rumen fluid at a slow rate which allowed hydrogenation of the fatty acids to occur but which prevented a high concentration of oil developing in the rumen and hence greatly reduced the effects of the oil on digestion of $\mathrm{OM}$ and fibre. These results demonstrate the importance of distinguishing between protecting the rumen contents from the effects of the added lipid and protecting the lipid from metabolism by the rumen digesta. 


\section{CONCLUSIONS}

The free lipids clearly had major effects on rumen metabolism. The potential importance of these effects are both beneficial, in improving the efficiency of microbial protein synthesis, and deleterious, in reducing fibre digestion. The possibility of reducing the effects on fibre digestion while retaining the improved efficiency of synthesis clearly merits further study, but recent attempts to achieve these effects by reducing the amount of linseed oil were unsuccessful (Ikwuegbu \& Sutton, 1982). It was noteworthy that both the oils had essentially the same effect on rumen processes despite their very different fatty acid compositions. The linseed oil was rich in $\mathrm{C}_{18}$ unsaturated fatty acids, containing $(\mathrm{mg} / \mathrm{g})$ 18:1 173, 18:2 149 and 18:3 556, whereas the coconut oil contained 12:0 446 and 14:0 163 and a total of only $77 \mathrm{mg} \mathrm{C}_{18}$ unsaturated fatty acids/g. All these fatty acids have been shown to be inhibitory to certain rumen bacteria, particularly the cellulolytic species, in vitro (Henderson, 1973) so it is not possible to tell from the results how far the effects on fibre digestion represented specific effects of fatty acids on bacterial metabolism and how far they were due to more generalized coating effects of either the microbes or the feed particles. However, the stimulatory effect of both oils on microbial protein synthesis clearly showed that at least part of the action of the oils was a direct effect on the microbes.

Even when associated with a reduction in OM digestion in the rumen, the increased efficiency of microbial synthesis resulted in an increased total flow of non-ammonia-N and microbial $\mathrm{N}$ to the duodenum. To achieve this, between 6.1 and $7.1 \mathrm{~g} \mathrm{~N} / \mathrm{d}$ were added to digesta between the mouth and proximal duodenum. Assuming that $0.03 \mathrm{~g} \mathrm{~N} / \mathrm{d}$ per $\mathrm{kg}$ body-weight (Harrop, 1974) were secreted in the abomasum, then between approximately 5 and $6 \mathrm{~g} \mathrm{~N} / \mathrm{d}$ were re-cycled to the rumen. The ability to re-cycle large amounts of $\mathrm{N}$ to the rumen is well-established for wether sheep given low-N diets at maintenance but it is arguable that a high-producing animal, such as a fast-growing calf or a high-yielding dairy cow, would be far less capable of re-cycling $\mathbf{N}$ because of the large demands for tissue $\mathbf{N}$. In such animals there would appear to be considerable potential for adding non-protein- $\mathrm{N}$ to oil-supplemented diets to fulfil the increased $\mathbf{N}$ demands of the rumen microbes caused by the oils. The interaction between urea and lipid supplements was examined by Ørskov et al. (1978) in lambs given dried grass as a basal diet. They found slightly greater responses to urea supplementation, in terms of feed intake and acid-detergent fibre digestion, when dried grass was given with tallow than when it was given alone, but this effect of urea was primarily an alleviation of the depression in intake and digestibility caused by the tallow rather than a positive stimulation. No measurements of $\mathrm{N}$ metabolism were reported.

The authors are grateful to Dr J. E. Storry for helpful discussions during the course of this work, Dr H. L. Buttle and the late Mr S. C. Watson for cannulation of the sheep, Mr S. V. Morant for assistance with statistical analyses, Messrs D. J. Napper and V. W. Johnson for help in caring for the animals and Messrs E. Schuller and E. Florence for some of the chemical analyses. R.K. gratefully acknowledges receipt of an Agricultural Research Council studentship.

\section{REFERENCES}

Agricultural Research Council (1980). The Nutrient Requirements of Ruminant Livestock. Slough: Commonwealth Agricultural Bureaux.

Ash, R. W. (1962). Anim. Prod. 4, 309.

Bergen, W. G. \& Yokoyama, M. T. (1977). J. Anim. Sci. 46, 573.

Bines, J. A., Brumby, P. E., Storry, J. E., Fulford, R. J. \& Braithwaite, G. D. (1978). J. agric. Sci., Camb. 91, 135 .

Cammell, S. B. (1977). Tech. Rep. Grassld Res. Inst. no. 24, p. 4.

Conway, E. J. (1957). Microdiffusion Analysis and Volumetric Error, 4th ed. London: Crosby Lockwood. 
Corse, D. A. \& Sutton, J. D. (1971). Proc. Nutr. Soc. 30, 18 A.

Czerkawski, J. W., Christie, W. W., Breckenridge, G. \& Hunter, M. L. (1975). Br. J. Nutr. 34, 25.

Demeyer, D. I. \& Van Nevel, C. J. (1979). Br. J. Nutr. 42, 515.

Devendra, C. \& Lewis, D. (1974a). Ind. J. Anim. Sci. 44, 917.

Devendra, C. \& Lewis, D. (1974b). Malay. agric. Res. 3, 228.

Faichney, G. J. (1975). In Digestion and Metabolism in the Ruminant, p. 277 [I. W. McDonald and A. C. I. Warner, editors], Armidale: University of New England.

Harrison, D. G., Beever, D. E. \& Osbourn, D. F. (1979). Br. J. Nutr. 41, 521.

Harrison, D. G. \& McAllan, A. B. (1980). In Digestive Physiology and Metabolism in Ruminants, p. 205 [Y. Ruckebusch and P. Thivend, editors]. Lancaster: MTP.

Harrop, C. J. F. (1974). J. agric. Sci., Camb. 83, 249.

Henderson, C. (1973). J. agric. Sci., Camb. 81, 107.

Hogan, J. P., Connell, P. J. \& Mills, S. C. (1972). Aust. J. agric. Res. 23, 87.

Ikwuegbu, O. A. \& Sutton, J. D. (1982). Br. J. Nutr. 48, 365.

Knight, R., Sutton, J. D., McAllan, A. B. \& Smith, R. H. (1978). Proc. Nutr. Soc. 37, 14A.

Knight, R., Sutton, J. D. \& Storry, J. E. (1977). Proc. Nutr. Soc. 36, 69A.

Leng, R. A. (1970). In Physiology of Digestion and Metabolism in the Ruminant, p. 406 [A. T. Phillipson, editor]. Newcastle upon Tyne: Oriel.

McAllan, A. B., Knight, R. \& Sutton, J. D. (1983). Br. J. Nutr. 49, 433.

McAllan, A. B. \& Smith, R. H. (1969). Br. J. Nutr. 23, 671.

Newport, M. J., Storry, J. E. \& Tuckley, B. (1979). Br. J. Nutr. 41, 85.

Ørskov, E. R., Hine, R. S. \& Grubb, D. A. (1978). Anim. Prod. 27, 241.

Palmquist, D. L. \& Jenkins, T. C. (1980). J. Dairy Sci. 63, 1.

Scott, T. W., Cook, L. J. \& Mills, S. C. (1971). J. Am. Chem. Soc. 48, 358.

Smith, R. H. \& McAllan, A. B. (1974). Br. J. Nutr. 31, 27.

Smith, R. H., McAllan, A. B., Hewitt, D. \& Lewis, P. E. (1978). J. agric. Sci., Camb. 90, 557.

Stevenson, A. E. \& de Langen, H. (1960). N.Z. Jl agric. Res. 3, 314.

Sutton, J. D. (1979). Proc. Nutr. Soc. 38, 275.

Sutton, J. D. \& Johnson, V. W. (1969). J. agric. Sci., Camb. 73, 459.

Sutton, J. D., Smith, R. H., McAllan, A. B., Storry, J. E. \& Corse, D. A. (1975). J. agric. Sci., Camb. $84,317$.

Thomson, D. J., Beever, D. E., Coelho da Silva, J. F. \& Armstrong, D. G. (1972). Br. J. Nutr. $28,31$.

Van Nevel, C. J. \& Demeyer, D. I. (1981). Arch. Tierernahr. 31, 141.

Van Soest, P. J. \& Wine, R. H. (1967). J. Ass. Off. analyt. Chem. 50, 50. 